Premiere Educandum: Jurnal Pendidikan Dasar dan Pembelajaran

Volume 8(1) 78 - 87 Juni 2018

Copyright (C2018 Universitas PGRI Madiun

ISSN: 2088-5350 (Print) / ISSN: 2528-5173 (Online)

Available at: http://e-journal.unipma.ac.id/index.php/PE

Doi: $10.25273 /$ pe.v8i1.2560

\title{
Perpektif guru sekolah dasar terhadap Higher Order Tinking Skills (HOTS): pemahaman, penerapan dan hambatan
}

\author{
Subroto Rapih ${ }^{1}$, Sutaryadi ${ }^{2}$ \\ ${ }^{1}$ Fakultas Keguruan Dan Ilmu Pendidikan, Universitas Sebelas Maret \\ 1email: Subrotorapih_89@staff.uns.ac.id \\ ${ }^{2}$ Fakultas Keguruan Dan Ilmu Pendidikan, Universitas Sebelas Maret \\ ${ }^{2}$ email: sutaryadi@staff.uns.ac.id
}

\begin{abstract}
Higher Order Thinking Skills (HOTS) is a way of thinking that put forward the values of critical thinking and creative so that it is considered capable of providing solutions in facing the challenges of the times. The purpose of this research is to know and give an idea about the understanding of elementary school teacher in HOTS. This research used survey research method and the research approach used is descriptive quantitative. Instruments in the data collection using closed questionnaires that are distributed directly to the respondent. Furthermore, data in this research is analyzed by quantitative descriptive data analysis technique. The results of this study indicate that $91.43 \%$ of respondents understand the concept of HOTS and $8.57 \%$ of respondents have not understood. As many as $85.71 \%$ of respondents think HOTS can be taught at the primary school level, $11.43 \%$ think HOTS can not be taught and $2.86 \%$ of respondents answered do not know. $82.86 \%$ of respondents have applied HOTS on learning activities and $17.14 \%$ of respondents have not applied. $79 \%$ of respondents had difficulties in designing and implementing HOTS-based evaluation, 59\% difficulties in the delivery of learning materials, $45 \%$ difficulty in designing instructional media, $38 \%$ difficulty in designing learning tools and $31 \%$ difficulty in the process of compiling teaching materials.
\end{abstract}

Key Words: Higher Order Skills Thinking (HOTS), Teachers, Elementery Schools.

\begin{abstract}
Abstrak
Higher Order Thinking Skills (HOTS) merupakan cara berfikir yang mengedepankan nilai-nilai berfikir kritis dan kreatif sehingga dipandang mampu memberikan solusi dalam menghadapi tantangan perkembangan zaman. Tujuan dari penelitian ini yaitu untuk mengetahui dan memberikan gambaran tentang pemahaman guru kelas Sekolah Dasar (SD) terhadap HOTS. Penelitian ini menggunakan metode penelitian survey sedangkan pendekatan penelitian yang digunakan adalah deskritptif kuantitatif. Instrumen dalam pengambilan data menggunakan kuisioner/ angket tertutup yang dibagikan langsung kepada responden. Selanjutnya, data dalam penlitian ini dianalisis dengan teknik analisis data deskriptif kuantitatif. Hasil penelitian ini menunjukkan bahwa 91,43\% responden memahami konsep dari HOTS dan 8,57\% responden belum memahami. Sebesar $85,71 \%$ responden berpendapat HOTS bisa diajarkan pada tingkat sekolah dasar, $11,43 \%$ berpendapat HOTS belum bisa diajarkan dan 2,86\% responden menjawab tidak tahu. $82,86 \%$ responden sudah menerapkan HOTS pada kegiatan pembelajaran dan 17,14\% responden belum menerapkan. Sebesar 79\% responden kesulitan dalam merancang dan menerapkan evaluasi berbasiskan HOTS, 59\% kesulitan dalam penyampaian materi pembelajaran, $45 \%$ kesulitan dalam merancang media pembelajaran, $38 \%$ kesulitan dalam merancang perangkat pembelajaran dan sebesar $31 \%$ kesulitan dalam proses penyusunan bahan ajar.
\end{abstract}

Kata kunci: Higher Order Skills Thinking (HOTS), Guru, Sekolah Dasar

Histori artikel : disubmit pada 30 Mei 2018; direvisi pada 02 Juni 2018; diterima pada 16 Juni 2018 


\section{A. PEDAHULUAN}

Perkembangan ilmu pengetahuan dan teknologi menuntut adaptasi yang baik dalam dunia pendidikan. Dunia pendidikan sebagai sarana dalam pengembangan ilmu pengetahuan dan teknologi harus terus berkembang dan berproses seuai dengan perkembangan zaman. Standar-standar dalam output maupun outcome pendidikan juga terus mengalami peningkatan seiring dengan perubahan dan tuntutan zaman. Salah satu isu terkini dalam dunia pendidikan modern adalah pembentukan Higher Order Skills Thinking (HOTS) bagi peserta didik.

HOTS merupakan suatu tigkat berfikir yang menekankan pada penerapan pengetahuan yang telah diterima, penelaran reflkesi, pemecahan masalah, pengambilan keputusan dan selanjutnya merumuskan pada suatu hal yang baru (Sulaiman, Muniyan, Madhvan, Hasan \& Rahim, 2017; Widodo, 2013; Brookhart, 2010; King, Goodson \& Rohani, 2006). HOTS merupakan suatu keahlian dalam berfikir yang mencakup hal-hal di atas. Peserta didik yang mnecapai level HOTS akan mampu menerapkan pengetahuan secara kreatif dan kritis sehingga suatu pengetahuan akan terus di proses dan akhirnya akan mneghasilkan suatu pemecahan masalah.

Konsep HOTS berasal dari teori taksonomi Bloom (1956) dalam ranah kognitif yang melibatkan perkembangan keterampilan intelektual dan secara bertahap berkembangan dari cara berfikir konkret ke abstrak (Forehand, 2010; Pappas, Pierakos \& Nagel, 2012). Dalam HOTS, peserta didik diharuskan mneguasi suatu pengetahuan dalam level menganalisis (Analyze), mengevaluasi
(Evaluated) dan mencipta (Created). Sehingga daya nalar dan daya kritis berfikir siswa sangat dibutuhkan dalam HOTS. Keterampilan-keterampilan tersebut yang menjadi inti dalam HOTS merupakan modal utama peserta didik dalam menjalani kehidupan. Konsep HOTS telah mengalami beberapa pengembangan dan faktor-faktor yang berkontribusi terhadap pengembangan HOTS pada peserta didik telah menjadi bahan kajian selama beberapa tahun terakhir (Noble \& Powell, 1995; Rajendran, 2001; O'Tuel \& Bullard, 2001; Marshall, Robert \& Horton, 2011; Magno, 2011; Fischer, Bol \& Pribesh, 2011; Kondak \& Ayden, 2013). Berdasarkan beberapa kajian dan penelitian, faktor-faktor yang mempengaruhi HOTS antara lain: lingkungan kelas, karakteristik keluarga, karakteristik psikologis, dan kecerdasan (Horan, 2007; Silvia, 2008; Pannells \& Claxton, 2008; Lim \& Smith, 2008; Chini, Charmichael, Robello \& Puntambekar, 2009; Pascarella, Wang, Trolian \& Blaich, 2013; Fearon, Copeland \& Saxon, 2013; Lather, Jain \& Shukla, 2014).

Urgensi dari HOTS menjadi semakin kuat ketika The Partnership 21st century skills (2011) merumuskan kerangka kerja pembelajaran abad 21. Dalam kerangka kerja tersebut, konten akadmik yang berupa 3rs (Writing, reading dan aritmethics) dan $4 \mathrm{cs}$ (berfikir kritis, pemecahan masalah, kolaborasi dan kreativitas dan innovasi) merupakan hal sangat penting dalam kegiatan pembelajaran di abad 21. Jika merujuk dalam kerangka kerja tersebut, maka HOTS merupakan jawaban dalam menjawab tantangan dalam pembelajaran abad 21. Disamping itu, dengan HOTS 
siswa akan terbiasa berpikir kritis dan kreatif baik dalam pengambilan keputusan dan pemecahan masalah yang berkaitan dengan menganalisis, mengevaluasi dan mencipta (Anderson \& Krathwohl, 2001).

Untuk mencapai tujuan dalam pembentukan HOTS pada peserta didik, maka diperlukan suatu proses pembelajaran yang harus mengakomodir perkembangan HOTS. Pembelajaran yang aktif, berpusat pada siswa, pembentukan rasa ingin tahu (keinginan bertanya) dan penilaian yang berdasar pada HOTS merupakan salah satu cara untuk pencapaian peserta didik ke HOTS (Boaler \& Staples, 2008; Franco, Sztajn, \& Ortigao, 2007). Penekanan utama dalam kegiatan pembelajaran guna membentuk HOTS adalah pada prose pembelajaran Student Center Learning (SCL). Peserta didik yang mengikuti kegiatan pembelajaran dengan model SCL dan mendapatkan tantangantantangan selama mereka belajar terbukti menunjukkan pertumbuhan otan 25\% lebih cepat dibandingkan dengan yang tidak mendapatkan perlakuan tersebut (Jakobs, 1993; Conklin \& Manfro, 2012).

Pembelajaran untuk mencapai HOTS memerlukan sinergi yang kuat antara seluruh pelaku pendidikan. Dimulai dari kurikulum sebagai fundamen dasar kegiatan pendidikan harus diterapkan secara koprehensif dan kontekstual. Kurikulum beserta komponen-komponen dibawahnya termasuk pelaku utama yaitu guru dituntut untuk terus berupaya mengembangkan keahlian dalam proses pembelajaran agar peserta didik mencapai tingkatan HOTS. Di Indonesia sendiri, diterapkannya kurikulum 2013 sebenarnya merupakan fondasi kuat guna mencapai HOTS pada peserta didik. Dari sisi teknis pembelajaran di kelas, untuk mencapai HOTS dapat dilakukan minimal dengan beberapa cara salah satunya dengan memberikan beberapa motivasi yang dapat dilakukan guru di kelas (Conklin \& Manfro, 2010: 18). Motivasi-motivasi tersebut dapat berupa : 1) membuka dan mengakhiri pelajaran dengan pertanyaan- pertanyaan yang mengarah pada keterampilan berpikir tingkat tinggi, 2) menempatkan aktivitas brainstorming pada pertengahan pelajaran untuk mendorong siswa menemukan ide dan berpikir kreatif, 3) memberikan tugas berbasis open ended sebagai pekerjaan rumah untuk mengetahui kreativitas dan pemahaman mereka terhadap pelajaran yang sudah dipelajari (Hidayati, 2018).

Penerapan kurikulum 2013 pada tingkat dasar sampai menengah merupakan upaya dalam meningkatkan kualitas output dan outcome pendidikan di Indonesia. Kurikulum 2013 sebagai sarana dalam pencapaian HOTS sejak tingkatan Sekolah dasar (SD) merupakan upaya yang sangat bagus dalam meningkatkan kualitas berfikir siswa sedini mungkin. Melatih peserta didik agar pada tingkatan HOTS juga akan lebih baik jika dimulai sejak bangku sekolah dasar. Berdasarkan teori perkembangan, siswa sekolah dasar sudah mampu untuk mulai dikenalkan dengan model-model pembelajaran yang merangsang untuk mencapai HOTS.

Dengan modal fundamen dasar pendidikan yang sudah mulai dirintis berupa kurikulum 2013, pelaksanaan pembelajaran untuk mewujudkan HOTS pada siswa SD sebenarnya sudah berada pada jalur yang benar. Namun, beberapa hambatan sampai saat ini masih banyak dijumpai baik dari sisi penerapan 
kurikulum maupun dari sisi pembelajaran dalam perpektif HOTS. Lemahnya implementasi kurikulum 2013 yang disebabkan berbagai faktor menjadikan hasil produk dari kurikulum tersebut sampai saat ini belum optimal. Penelitian-penelitian mengenai problematika implementasi kurikulum 2013 secara garis besar mendapatkan hasil yang sejalan. Berdasarkan hasil penelitian, permasalahan implementasi kurikulum 2013 ada pada 3 ranah yaitu ranah pemerintah, ranah institusi (sekolah) dan ranah guru (Ahmad, 2014; Krissandi \& Rusmawan, 2015; Wahyudi \& Chamdani 2017). Pada ranah guru kendalam implementasi kurikulum 2013 secara garis besar meliputi kurang efektifnya pelatihan guru, pemahaman tentang konsep dan prosedur penilaian, pembuatan media pembelajaran, pemahaman guru, pemaduan antarmuatan pelajaran dalam pembelajaran tematik, dan penguasan teknologi informasi (Ahmad, 2014; Krissandi \& Rusmawan, 2015; Wahyudi \& Chamdani 2017).

Kunci untuk mencapai tingkatan HOTS adalah dalam pembelajaran sehingga guru mempunyai peran yang sangat penting dalam upaya menjadikan siswa mampu berada pada level HOTS. Sampai saat ini permasalahan utama yaitu guru belum mengetahui bagaimana cara mengajarkan pembelajaran yang menuju HOTS (Hidayati, 2018). Tujuan dari penelitian ini yaitu untuk mengetahui dan memberikan gambaran tentang pemahaman guru kelas Sekolah Dasar terhadap HOTS. Selain itu, penelitian ini juga mencoba untuk memberikan gambaran tentang pembelajaran yang dilakukan oleh guru kelas SD guna mencapai tingkatan HOTS. Hasil penelitian ini diharapkan akan menjadi bahan masukan dalam perumusan kebijakan terutama dalam pengembangan kompetensi guru.

\section{B. METODE PENELITIAN}

Penelitian ini menggunakan metode penelitian survey sedangkan pendekatan penelitian yang digunakan adalah deskritptif kuantitatif. Azwar (2009) mendefinsikan penelitian deskriptif sebagai suatu peneitian yang melakukan analisis hanya sampai pada taraf deskripsi, yaitu menganalisis dan menyajikan fakta secara sistematik sehingga dapat lebih mudah untuk difahami dan disimpulkan.

Instrumen dalam pengambilan data menggunakan kuisioner/ angket tertutup yang dibagikan langsung kepada responden. Angket terdiri dari 25 item pertanyaan. Selanjutnya, data dalam penlitian ini dianalisis dengan teknik analisis data deskriptif kuantitatif.

Populasi dalam penelitian adalah seluruh guru tetap baik yang bersetatus Pegawai Negeri Sipil (PNS) ataupun Guru Tetap Yayasan (GTY) Sekolah dasar (SD) negeri dan swasta di eks karisidenan Surakarta yang meliputi Kota Surakarta, Kabupaten Sukoharjo, Kabupaten Boyolali, Kabupaten Wonogiri, Kabupaten Klaten, Kabupaten Karanganyar dan Kabupaten Sragen. Teknik pengambilan sampel menggunakan teknik purposive sampling sehingga didapatkan sampel sejumlah 35 guru yang mewaili masing-masing Kabupaten/ Kota (Masing-masing Kabupaten/ Kota sebanyak 5 guru). Asal sekolah dari masing-masing sampel diambil secara acak dan tidak memandang status baik itu sekolah negeri atau swasta. 


\section{HASIL DAN PEMBAHASAN}

Hasil penelitian ini merupakan hasil pengolahan data angket yang telah dibagikan dan diisi oleh responden. Total ada 35 angket yang dibagikan dan keseluruhan angket berhasil dikumpulkan dan telah diisi oleh responden.

1. Karakteristik responden

Karakteristik responden secara lengkap data dilihat pada tabel di bawah ini:

Tabel 1. Karakteristik Responden

\begin{tabular}{|c|c|c|c|}
\hline $\begin{array}{l}\mathbf{N} \\
\mathbf{0 .}\end{array}$ & Data responden & Jumlah & $\begin{array}{c}\text { Persenta } \\
\text { se }\end{array}$ \\
\hline \multirow[t]{4}{*}{1.} & Jenis Kelamin & & \\
\hline & Laki-laki & 14 & $40 \%$ \\
\hline & Perempuan & 21 & $60 \%$ \\
\hline & Total & 21 & $100 \%$ \\
\hline \multirow[t]{8}{*}{2.} & Lama Mengajar & & \\
\hline & 1 sampai 5 Tahun & 2 & $5,71 \%$ \\
\hline & $\begin{array}{ll}6 \text { sampai } & 10 \\
\text { tahun } & \end{array}$ & 8 & $22,86 \%$ \\
\hline & 11 sampai 15 & & \\
\hline & Tahun & 12 & $34,29 \%$ \\
\hline & Lebih dari 15 & & \\
\hline & Tahun & 13 & $37,14 \%$ \\
\hline & Total & 35 & $100 \%$ \\
\hline \multirow[t]{5}{*}{3.} & $\begin{array}{l}\text { Pendidikan } \\
\text { Terakhir }\end{array}$ & & \\
\hline & $\mathrm{S} 1$ & 29 & $82,86 \%$ \\
\hline & S2 & 6 & $17,14 \%$ \\
\hline & S3 & 0 & $0 \%$ \\
\hline & Total & 35 & $100 \%$ \\
\hline \multirow[t]{4}{*}{4.} & Status & & \\
\hline & PNS & 26 & $74,29 \%$ \\
\hline & GTY & 9 & $25,71 \%$ \\
\hline & Total & 35 & $100 \%$ \\
\hline \multirow[t]{4}{*}{5.} & $\begin{array}{l}\text { Status sertifikasi } \\
\text { Guru }\end{array}$ & & \\
\hline & Tersertifikasi & 28 & $80 \%$ \\
\hline & $\begin{array}{l}\text { Belum } \\
\text { tersertifikasi }\end{array}$ & 7 & $20 \%$ \\
\hline & Total & 35 & $100 \%$ \\
\hline
\end{tabular}

Berdasarkan tabel di atas, dapat dilihat bahwa responden mayoritas adalah guru perempuan dengan persentase $60 \%$ dan sisanya adalah guru laki-laki dengan persentase $\quad 40 \%$. Responden memiliki pengalaman mengajar cukup beragam, berdasarkan data dari angket yang telah terkumpul, mayoritas reponden sudah mnegajar selama lebih dari 15 tahun yaitu sebesar 37\% dan berturut-turut telah mengajar selama 11-15 tahun sebesar $34 \%$, telah mengajar selama 6-10 tahun sebesar $23 \%$ dan terakhir telah mengajar selama 1-5 tahun sebesar 6\%. Data tersebut menunjukkan bahwa mayoritas guru adalah guru senior dengan pengalaman mengajar lebih dari 15 tahun.

Pendidikan terakhir responden mayoritas adalah berijazah sarjana (S1) sebesar $83 \%$ dan sisanya berijazah s2 sebesar $17 \%$. Sedangkan untuk status responden, sebanyak 74\% responden bersetatus sebagai Guru Pegawai negeri Sipil (PNS) dan sisanya sebesar $26 \%$ bersetatus sebagai Guru Tetap Yayasan (GTY) sebesar $26 \%$. Untuk status sertifikasi guru, sebanyak $80 \%$ responden telah bersetatus sebagai guru bersertifikasi dan sisanya sebesar $20 \%$ merupakan guru belum tersertifikasi.

2. Pemahaman tentang Higher Order Thinking Skills (HOTS)

Pada pertanyaan ini, responden diajukan pertanyaan tentang pengetian dari konsep HOTS. Berdasarkan hasil angket yang terkumpul sebanyak $91,43 \%$ mengetahui pengertian dari konsep HOTS dan sisanya yaitu sebanyak $8,57 \%$ tidak mengetahui pengertian dari konsep HOTS. Secara singkat persentase jawaban dari pertanyaan ini dapat dilihat pada bagan di bawah ini: 


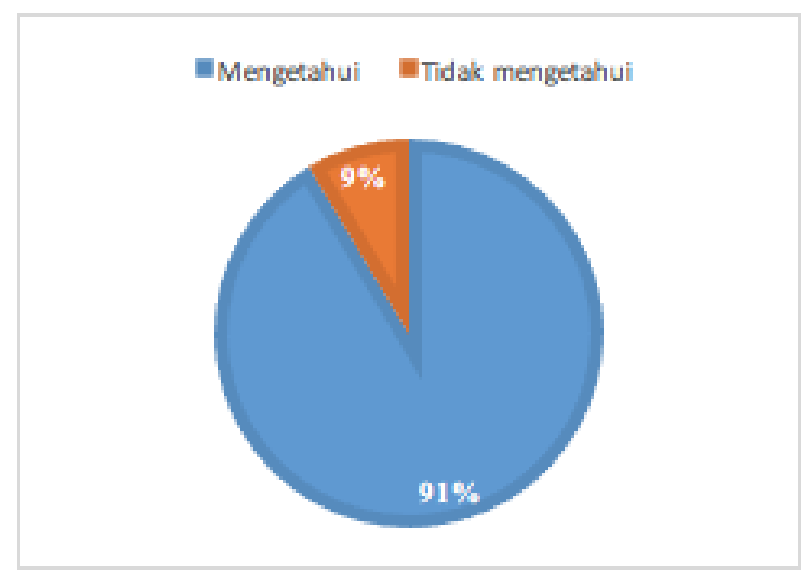

Gambar 1. Pesentase pemahaman konsep HOTS.

Berdasarkan jawaban responden dari item pertanyaan ini, mayoritas responden $(91,43 \%)$ atau sebanyak 32 guru sudah memahami konsep dari HOTS. Namun demikian, masih ditemukan sebanyak 3 guru atau $8,57 \%$ responden yang belum mengetahui konsep dari HOTS. Walaupun kecil, namun hal ini sangat memerlukan upaya serius guna memberikan pemahaman kepada guru mengenai konsep HOTS karena jika tidak mengetahui konsep bisa dipastikan tidak akan bisa menerapkan pembelajaran berbasiskan HOTS. Hal ini sejalan dengan penelitian yang dilakukan oleh Syaodih \& Handayani (2014) dimana masih terdapat guru yang masih kebingungan dalam penerapan pembelajaran berbasiskan HOTS.

3. Pemahaman HOTS untuk diajarkan pada siswa Sekolah Dasar (SD)

Pertanyaan ini ditujukan kepada responden untuk mengetai sudut pandang responden tentang apakah HOTS dapat diajarkan pada siswa Sekolah dasar (SD). Berdasarkan jawaban responden sebanyak $85,71 \%$ responden berpendapat bahwa HOTS dapat dimulai diajarkan pada siswa sekolah dasar, selanjutnya sebanyak $11,43 \%$ berpendapat bahwa HOTS belum bisa dimulai diajaran pada siswa sekolah dasar dan sisanya sebanyak $2,86 \%$ responden menjawab tidak tahu (Gambar 2).

Hal ini tentu merupakan temuan yang cukup penting dimana mash terdapat guru yang menganggap bahwa HOTS belum bisa diajarkan pada siswa Sekolah dasar. Berdasarkan penelitian yang dilakukan oleh Usmaedi (2017) HOTS seharusnya sudah mulai diajarkan dan dilatih sedini mungkin. HOTS merupakan suatu kemmapuan berfikir yang mneyesuaikan tingkatan kognitif seseorang. Siswa pada usia sekolah dasar tentunya wajib mulai dikenalkan dengan HOTS sesuai dengan perkembangan kognitif di usia tersebut. Dengan demikan HOTS akan terus berkembang seiring dengan perkembangan kognitif siswa. 


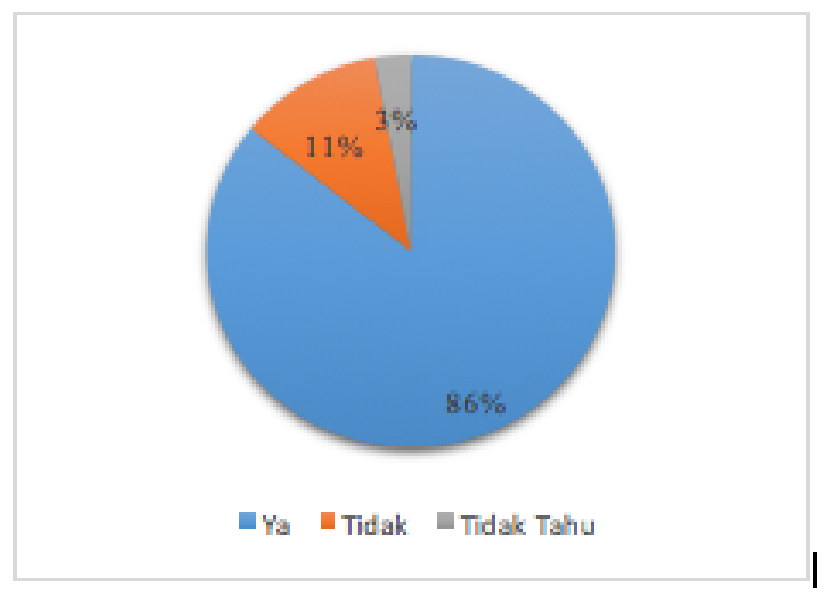

Gambar 2. Pendapat responden tentang HOTS pada siswa Sekolah dasar

4. Penerapan pembelajaran berbasiskan HOTS

Pada item pertanyaan ini, responden diberikan pertanyaan mengenai implementasi HOTS dalam pembelajaran. Yang dimaksud implementasi dalam pertanyaan ini tidak difokuskan dalam bagian tertentu, namun mencakup pada kegiatan perencanaan, penerapan dan evaluasi pembelajaran. Walaupun responden hanya menerapkan pada salah satu kegiatan maka hal tersebut tetap dianggap sudah melaksanan. Berdasarkan jawaban yang diberikan responden, sebanyak $82,86 \%$ atau sebanyak 29 responden menjawab sudah menerapkan pembelajaran berbasiskan HOTS dan sisanya sebanyak $17,14 \%$ atau 6 responden belum menerapkan pembelajaran berbasiskan HOTS dalam kegiatan apapun (Gambar 3).

Temuan ini sebenarnya memberikan harapan yang bagus dimana mayoritas guru sudah mulai menerapkan nilai-nilai HOT dalam kegiatan pembelajaran. Namun hal ini tidak sejalan dengan temuan dilapangan bahwa masih banyak siswa yang belum memiliki HOTS ketika lulus. Disamping itu, dari ranking Program For International Students Assesment (PISA) terlihat kemampuan berfikir tingkat tinggi siswa Indonesia menempati posisi rendah dibandingkan dengan negara lain. Dengan demikian masih perlu evaluasi dan pendalam yang lebih jauh tentang bentuk dan cara penerapan pembelajaran berbasiskan HOT yang telah dilakukan oleh guru.

Dari atau $82,86 \%$ responden yang menjawab sudah menerapkan pembelajaran berbasiskan HOTS, diberikan pertanyaan lebih lanjut mengenai pada kegiatan apa yang sudah berbasiskan HOTS. Terdapat 3 pilihan jawaban yaitu persiapan/ perencanaan, pelaksanaan dan evaluasi. Pada pertanyaan lanjutan ini, keseluruhan responden atau sebanyak $100 \%$ sudah menanamkan nilai-nilai HOTS pada level perencanaan pembelajaran, sedangkan sebanyak $62 \%$ responden hanya menerapkan pembelajaran berbasiskan HOTS pada pelaksanaan pembelajaran dan sebanyak $28 \%$ resonden mengaku menerapkan kegiatan pembelajaran berbasiskan 
HOTS pada keigiatan evaluasi (Gambar 4).

Keseluruhan responden mengaku sudah menerapkan nilainilai HOT dalam perencanaan pembelajaran. Pada tahapan perencanaan yaitu penyusunan perangkat pembelajaran merupakan jenis kegiatan yang paling mudah dalam implementasi nilai-nilai HOT. Sedangkan jenis kegiatan yang paling rendah dalam penerapan nilainilai HOT ada pada kegiatan evaluasi. Hal ini sejalan dengan penelitian-penelitian sebelumnya bawa evaluasi merupakan salah satu kegiatan yang belum optimal dalam implementasi

HOT.

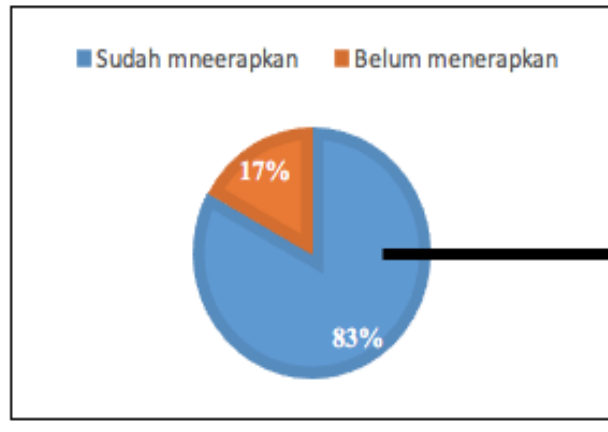

Gambar 3. Penerapan HOTS dalam pembelajaran

Gambar 4. Jenis kegiatan pembelajaran yang menerapkan HOTS

5. Kendala dalam penerapan kegiatan pembelajaran berbasiskan HOTS

Sebanyak 29 atau $83 \%$ yang telah menerapkan kegiatan pembelajaran berbasiskan HOTS, diberikan pertanyaan lanjutan yang menanyakan hambatan atau kendala yang dihadapi dalam menerapkan kegiaten pembelajaran berbasiskan HOTS. Berdasrakan jawaban yang diberikan responden, sebanyak 23 dari 29 responden atau $79 \%$ menjawab mengalami kesulitan dalam merancang dan menerapkan evaluasi berbasiskan HOTS. Selanjutnya sebanyak 17 dari 29 responden atau $59 \%$ responden manjawab kesulitan dalam penyampaian materi pembelajaran berbasiskan HOTS, kemudian sebanyak 13 dari 29 responden atau sebesar $45 \%$ responden menjawab kesulitan dalam merancang media

pembelajaran untuk menunjang kegiatan pembelajaran berbasiskan HOTS, selanjutnya sebanyak 11 dari 29 responden atau sebesar 38\% menjawab kesulitan dalam merancang perangkat pembelajaran berbasiskan HOTS dan sisanya sebanyak 9 dari 29 responden atau sebesar $31 \%$ menjawab kesulitan dalam proses penyusunan bahan ajar berbasiskan HOTS (Gambar 5).

Jawaban yang diberikan responden ini sejalan dengan data sebelumnya yaitu kesulitan utama yang dihadapi responden adalah dalam merancang evaluasi selanjutnya pada penyampaian materi menempati peringkat kedua sebagai faktor penghambat guru dalam penerapan nilai-nilai HOT pada kegiatan pembelajaran. Temuan ini memberikan masukan yang sangat berguna bagi peneliti lain 
ataupun pemangku kepentingan mampu menanamkan nilai-nilai HOT dalam penyusunan kegiatan-kegiatan dalam setiap kegiatan pembelajaran. peningkatan kompetensi guru agar

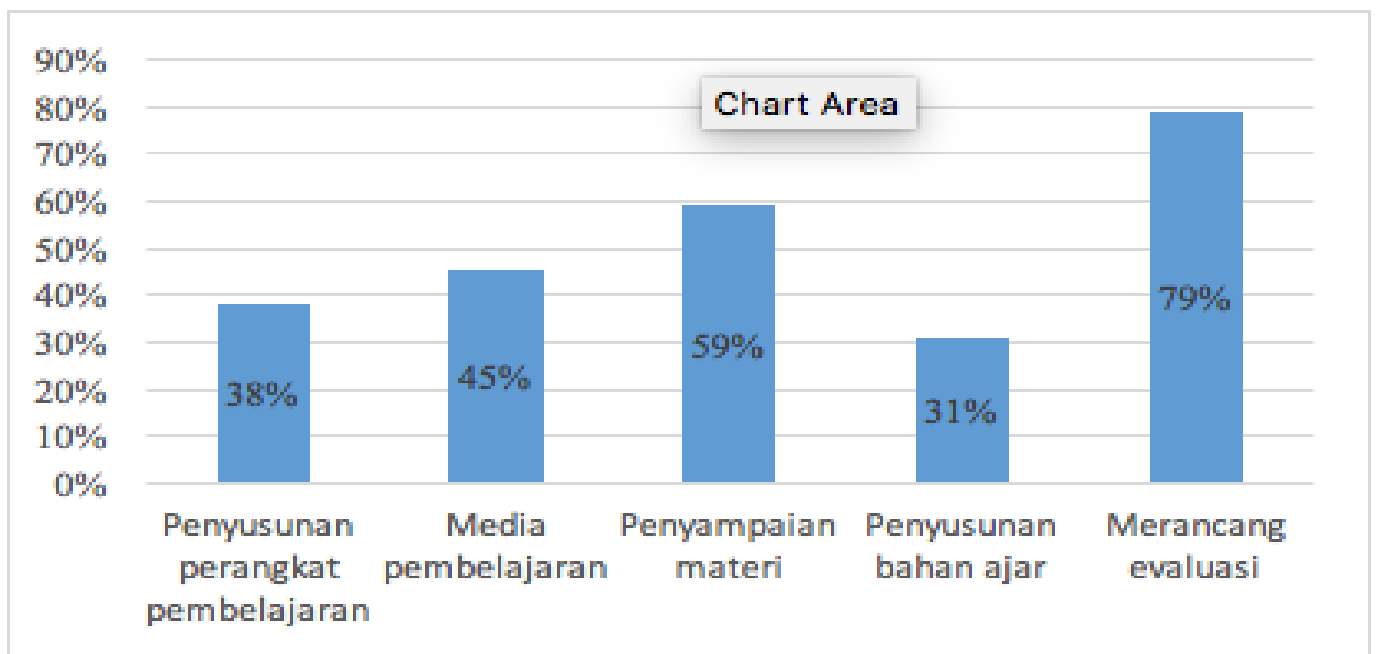

Gambar 5. Kendala yang dihadapi dalam penerapan kegiatan pembelajaran berbasiskan HOTS

Kendala pengimplementasian HOTS dalam kegiatan pembelajaran mayoritas pada kegiatan merancang evaluasi. Evaluasi yang dapat mnegukur sekaligus mengembangkan HOTS pada siswa haruslah disusun dengan mengedepankan nilai-nilai dalam HOTS itu sendiri. Kesulitan guru dalam penyususnan evaluasi dengan mengedepankan nilai-nilai HOTS juga ditemukan dalam penelitian yang dilakukan oleh Hidayati (2017). Selain itu, Gurupun ternyata juga mengalami kesulitan dalam mengajarkan bagaimana cara menyelesaikan masalah dengan baik (Suherman, Turmudi \& Rohayati, 2003:92). Untuk menanamkan nilai-nilai HOTS dalam evaluasi, salah satu strategi yang bisa dilakukan adalah dengan menyusun soal-soal yang bersifat non rutin atau open ended problem (soal terbuka). Menurut Suherman, Turmudi \& Rohayati (2003: 123) soal terbuka atau open ended adalah soal yang berbasiskan permasalahan yang diformulasikan memiliki multi jawaban yang benar atau disebut problem tak lengkap. Tujuan utama siswa diberikan masalah terbuka adalah siswa lebih ditekankan pada cara bagaimana sampai pada suatu jawaban. (Hidayati, 2017). Dengan demikian, siswa akan terlatih untuk berfikir multiperspektif dan non rutin sehingga berdampak pada kemampuan berfikir siswa yang semakin meningkat.

\section{SIMPULAN}

Hasil penelitian ini menunjukkan bahwa 91,43\% responden telah memahami konsep dari HOTS dan masih terdapat sebesar $8,57 \%$ responden yang belum memahami konsep dari HOTS. Sebanyak $85,71 \%$ responden berpendapat bahwa HOTS sudah bisa diajarkan pada tingkat sekolah dasar, selanjutnya sebanyak $11,43 \%$ berpendapat bahwa HOTS belum bisa diajarkan pada siswa sekolah dasar dan sisanya yaitu sebanyak $2,86 \%$ responden menjawab tidak tahu. Sebanyak $82,86 \%$ responden sudah menerapkan HOTS pada kegiatan pembelajaran dan sebanyak $17,14 \%$ 
responden belum menerapkan. Dari $82,86 \%$ responden yang sudah menerakan HOTS dalam pembelajaran, sebanyak $100 \%$ sudah menanamkan nilai-nilai HOTS pada level perencanaan pembelajaran, sedangkan sebanyak $62 \%$ pada pelaksanaan pembelajaran dan $28 \%$ resonden pada keigiatan evaluasi. Pada responden yang telah menerapkan HOTS dalam kegiatan pembelajaran, sebesar 79\% mengalami kesulitan dalam merancang dan menerapkan evaluasi berbasiskan HOTS. Selanjutnya 59\% responden kesulitan dalam penyampaian materi pembelajaran, kemudian sebesar $45 \%$ responden kesulitan dalam merancang media pembelajaran, selanjutnya sebesar $38 \%$ menjawab kesulitan dalam merancang perangkat pembelajaran dan sisanya sebesar $31 \%$ menjawab kesulitan dalam proses penyusunan bahan ajar berbasiskan HOTS.

\section{DAFTAR RUJUKAN}

Ahmad, S. (2014). Problematika kurikulum 2013 dan kepemimpinan instruksional kepala sekolah. Jurnal Pencerahan, 8(2).

Anderson LW, Krathwohl, DR (2001). A taxonomy for learning, teaching, and assessing: A revision of Bloom's taxonomy of educational objectives. New York: Addison Wesley Logman.

Azwar, S. (2009). Metode Penelitian. Yogyakarta: Pustaka Pelajar.

Bloom, B. S. (1956). Taxonomy of educational objectives, Handbook I: The cognitive domain. New York, NY: McKay.

Brookhart, S. M. (2010). How to assess higher-order thinking skills in your classroom. ASCD.
Boaler, J., \& Staples, M. (2008). Creating mathematical futures through an equitable teaching approach: The case of Railside School. Teachers College Record, 110(3), 608-645.

Chini JC, Carmichael A, Rebello NS, Puntambekar S (2009). Does the Teaching Learning Interview Provide an Accurate Snapshot of Classroom Learning?. Proceedings of the 2009 Physics Education Research Conference, AIP Publications, July 29-30.

Conklin, W \& Manfro, J. 2010. Higher order thinking skills to develop 21st century learners. Shell Education Publishing, Inc. Huntington.

Fearon DD, Copeland D, Saxon TF (2013). The Relationship Between Parenting Styles and Creativity in a Sample of Jamaican Children. Creativity Res. J. 25(1): 119128.

Fischer C, Bol L, Pribesh S (2011). An Investigation of Higher-Order Thinking Skills in Smaller Learning Community Social Studies Classrooms. Am. Secondary Educ. 39(2):5-25.

Franco, C., Sztajn, P., \& Ortigão, M. I. R. (2007). Mathematics teachers, reform, and equity: results from the Brazilian National Assessment. Journal for Research in Mathematics Education, 393419.

Forehand, M. (2010). Bloom's taxonomy. Emerging perspectives on learning, teaching, and technology. Retrieved from http://projects.coe.uga.edu/epltt/in dex.php?title=Bloom $\% 27$ s_Taxon o my.

Hidayati, A. U. (2018). Melatih Keterampilan Berpikir Tingkat Tinggi Dalam Pembelajaran 
Matematika Pada Siswa Sekolah Dasar. Terampil: Jurnal Pendidikan Dan Pembelajaran Dasar, 4(2), 143-156.

Horan R (2007). The Relationship Between Creativity and Intelligence: A Combined YogicScientific Approach. Creativity Res. J. 19(2-3): 179-202.

King, F.J, Goodson, L., \& Rohani, F. (2006), Higher Order Thinking Skills: Definition, Teaching Strategies, and Assesment, London: A publication of the Educational Services Program.

Krissandi, A. D. S., \& Rusmawan, R. (2015). Kendala guru sekolah dasar dalam implementasi Kurikulum 2013. Cakrawala Pendidikan, (3).

Kondak EU, Ayden YC (2013). Predicting Critical Thinking Skills of University Students through Meta cognitive Self-Regulation Skills and Chemistry SelfEfficacy. Educational Sciences: Theory Pract. 13(1):666-670.

Lather AS, Jain S, Shukla AD (2014). Student's Creativity in Relation to Locus of Control: a Study of Mysore University, India. Int. J. Indian Psychol. 2(1): 146-165.

Lim S, Smith J (2008). The Structural Relationships of Parenting Style, Creative Personality, and Loneliness. Creativity Res. J. 20(4):412- 419.

Pannells TC, Claxton AF (2008). Happiness, Creative Ideation, and Locus of Control. Creativity Res. J. 20(1): 67-71.

Pascarella ET, Wang JS, Trolian TL, Blaich C (2013). How the instructional and learning environments of liberal arts colleges enhance cognitive development. Higher Educ. 66:569-583.

Magno C (2011). Assessing the Relationship of Scientific Thinking, Self- regulationin Research, and Creativity in a Measurement Model. Int. J. Res. Rev. 6(1):22-47.

Marshall JC, Robert M, Horton RM (2011). The Relationship of Teacher Facilitated, Inquiry Based Instruction to Student HigherOrder Thinking. School Science and Mathematics.

Noble J, Powell DA (1995).Factors Influencing Differential Achievement of Higher-order Thinking Skills, as Measured by PLAN. ACT Research Report Series, 95-4.

O'Tuel FS, Bullard RK (2001). Developing Higher Order Thinking in the Content Areas K12. USA, CA; Critical Thinking Press and Software.

Pappas, E., Pierrakos, O., \& Nagel, R. (2012). Using Bloom's Taxonomy to teach sustainability in multiple contexts. Journal of Cleaner Production. doi: 10.1016/j.jclepro.2012.09.039.

Rajendran N (2001). The Teaching of Higher-Order Thinking Skills in Malaysia. J. Southeast Asian Educ. 2(1):42-46.

Suherman, Turmudi, Suryadi Rohayati. 2003. Strategi pembelajaran matematika Contemporer. UPI . Bandung.

Sulaiman, T., Muniyan, V., Madhvan, D., Hasan, R., Syrene, S., \& Rahim, A. (2017). Implementation of Higher Order Thinking Skills in Teaching Of Science: A Case Study in Malaysia. International Research Journal of Education and Sciences (IRJES), 1. 
Syaodih, E \& Handayani, H. (2014). Metode Pengembangan Higher Order Thinking Skills (Hots) Pada Anak Usia Sekolah Dasar. Pedagogik-Pendas, 456.

Usmaedi, U. (2017). Menggagas Pembelajaran HOTS Pada Anak Usia Sekolah Dasar. Jurnal
Pendidikan Sekolah Dasar, 3(1), 82-95.

Wahyudi, w., \& Chamdani, m. (2017). Mplementasi kurikulum 2013 di sekolah dasar masalah dan solusinya (studi kasus di kabupaten

kebumen). Dwijacendekia jurnal riset pedagogik, 1(1). 